\title{
Role of libraries in developing an informed, educated and empowered nation
}

Ina Fourie

Department of Information Science, University of Pretoria, Lynnwood Road, Pretoria, South

Africa, 0002

ina.fourie@up.ac.za

Anika Meyer

Department of Information Science, University of Pretoria, Lynnwood Road, Pretoria, South Africa, 0002

anika.meyer@up.ac.za

\begin{abstract}
Purpose - Libraries of all types have often been called on to take on challenges ranging from information literacy and developing a reading culture to promoting social justice. In recent literature they have been challenged to contribute to the development of informed and educated nations - a big issue in developing countries. Sometimes even to empower people. This paper raises awareness for this call as important for developing as well as developed nations and the numerous issues, role players and lenses they need to bear in mind. As an opinion piece it can merely scratch the surface of raising awareness.
\end{abstract}

Design/methodology/approach - This contribution builds on the literature of library and information science, education and politics to present an exploratory viewpoint and a nascent model to support further work. It intentionally touches on a diversity of issues that may seem at odds with each other, but that in our opinion reflect the enormous scope to address and diversity of individual, institutional and global input and lenses that can make a difference.

Findings - Many obvious approaches to achieve the object of an informed and educated nation with empowered individuals can be noted such as focusing on information literacy, digital literacy and information fluency. However more awareness is required of the need to take a holistic view of issues to focus on such as tolerance and ethics, and the information behaviour and information practices of people in various contexts, and how changes in the awareness of needs to address and the need to seek information and support from diverse sources, can contribute. A first step would be to note the diversity that might contribute towards a holistic view of a global problem to which libraries can contribute.

Originality/value - There are limited publications on the topic in the library and information science literature although "developing an informed and educated nation" features in the mission and vision plans of some countries, and empowerment is sometimes specifically noted in publications on user education and information literacy. This paper offers an exploratory viewpoint to raise awareness to consider various approaches and threads to the topic and to not think only in terms of education and information literacy, but to recognise the full role libraries and librarians can play - also in reaching out to other role players such as users, governments, and grant providers.

Keywords - Education, Empowerment, Librarians, Libraries, Library functions, Social responsibility 


\section{INTRODUCTION}

Libraries at institutional level can play a key role in developing informed and educated nations and in empowering people; they, however, do not operate alone and are positioned with many other role players in a wider society. Furthermore the concepts (informed and educated nations and empowerment) and the role players can be examined through different lenses, including information behaviour, information literacy, and the learning sciences; how we look at things determine our insights and understanding and the solutions we seek. A close reading of the words used to discuss the concepts and perspectives can enrich our awareness of the deeper problems to be solved. Apart from the institutional and government perspective, a people's perspective must play a role as well. This can express itself at the individual level in two ways: first, through the key roles played by librarians as professional individual practitioners and managers who can create safe and pleasant learning spaces; and second, through the autonomous actions of library users, who are empowered by those spaces and by other library services, in order to become self-efficacious members of an educated nation. Each element in this triangle functions in combination with the other two in a society at large with other role players who might shape initiatives, for example, grant and funding foundations/bodies such as the Bill and Melinda Gates Foundation and UNESCO.

Without librarians, libraries can do nothing; without library users, librarians have achieved nothing. Without libraries and librarians, users can do very little. All can benefit from input and support from other role players in society at large and from applying different lenses to understanding the key concepts and the role players who might make a difference to an urgent challenge of global importance.

This paper is presented as a viewpoint noting the value of different threads to a global problem ranging from opportunities for elements in the triangle that can work towards "informed, educated and empowered nations", to the value of different lenses to the challenges faced. It is not intended as an in-depth exploration of solutions and earlier work that has been done; merely as a viewpoint to raise awareness for the call on libraries from developing as well as developed nations to contribute to building informed and educated nations and empowering people. To guide the reader in keeping track of the diversity of threads and issues (that may seem at odds with each other), a nascent (i.e. a developing) model is suggested in Figure 1. As the paper evolves this model is used to suggest further work needed.

The paper developed from a conference paper (Developing an informed and educated nation) delivered at the Library Management Conference, 30 September (Johannesburg, South Africa). The input of an anonymous reviewer in shaping refinement of the paper is acknowledged with gratitude.

\section{BACKGROUND}

The need to move forward, to address social exclusion and to ensure social justice and access to information for all is globally acknowledged (Igiamoh and Ogunwemimo, 2013; Jaeger, Shilton and Koepfler, 2016; Stilwell, 2016). It concerns health, jobs, human rights and especially education, and many other things. Calls for educating nations and for empowerment of individuals, and the importance of an educated nation have often been raised - with empowerment being the ultimate aim (Hart and Nassimbeni, 2013; Maswabi, Sethate, Sebusang and Taolo, 2011; Mgina and Lwehabura, 2011). In fact - centuries ago Napoleon Bonaparte already said: "Give me the educated mothers and I would give you an educated nation" (Mali, 1989). Jane Fonda proclaimed: "We can no longer waste time and money. Every day, more than 2, 000 girls in America, age 15-19, give birth - in the wealthiest, most educated nation in the world! Neither you or I should accept this statistic" 
(Fonda, 2009), and according to Matilda Amissah Arthur "A reading nation is an informed nation" (Addo, 2014).

Many benefits have been noted for educated nations such as strength, power, wealth and richness (Maswabi et al., 2011). There are many ways to work towards, and to achieve, global and educated nations. Some refer to steps; others to pathways to be taken. Most important in making progress, is recognising the value of ripple effects: educated parents can contribute to educated children, improvement in quality of life and life-long learning (Maswabi et al., 2011). Educated library users can make a difference, especially if they are also empowered to make a difference to information literacy training and library user education (Eden and Eden, 2015; Fourie, 1999; Nakhoda and Rahimian, 2015).

National visions, goals and missions can provide structure and direction (Nkwocha, 2011). Some countries have openly set specific goals and visions working towards an empowered and educated nation e.g. Vision 2016 in Botswana (Maswabi et al., 2011), as well as the Tanzania Development Vision 2025 (UNESCO, 2000). The ultimate aim of an empowered informed and educated nation - apart from learning organisations that have been noted for many years, should be learning societies, communities of practice, collaborative learning and information seeking, ethical conduct under all circumstances, the building of community resilience and health, improved self-efficacy (i.e. the belief in one's own abilities) amongst citizens and those leading the process, and support for people to develop and build social capital (Ash-Argyle and Shoham, 2014; Britz, 2008; Bronstein, 2014; Ellison, Vitak, Gray and Lampe, 2014; Okada, Mikroyannidis, Meister and Little, 2012; Poortinga, 2012). Tall orders that need to build on literacy, digital literacy, media literacy and education (Rix and PaigeSmith, 2011) amongst others. UNESCO (2015) offers a good example of an online media literacy course.

Libraries and librarians can play a prominent and successful role in developing informed and educated, as well as empowered nations. They, however face many realities and challenges: poor infrastructures, lack of funding, lack of well trained staff, policies, and government support. Means need to be find to address these; some options/solutions have been reported (Khan and Bhatti, 2012; Real, Bertot and Jaeger, 2014), but very few references could, however, be found when searching specifically for the phrases "informed nation", and "educated nation" in Library and Information Science databases such as Library and Information Science Abstracts (LISA), Library and Information Science Source, and Library, Information Science and Technology Abstracts (LISTA). The focus in the library and information science (LIS) literature is on the related and underlying issues.

A holistic view, acknowledging different threads and lenses that can be pursued, can contribute to addressing the global problem of "informed, educated and empowered nations" and the roles libraries, librarians and library users can play in collaboration with others. As said earlier - the first step is awareness of what is at stake.

\section{A NASCENT MODEL REFLECTING ROLE PLAYERS AND LENSES IN AWARENESS}

Libraries attempting to develop informed and educated nations face a complex but also rewarding challenge. Figure 1 presents a simplistic nascent model which can serve as point of departure for the rest of this paper. It touches on three important elements in the triangle of institutional and individual elements that can make a contribution, and that will be explored in more detail in further sections, as well as the need to consider society at large.

Eight key issues need to drive libraries' and librarians' efforts: (1) determining and working from the country's vision, goals, aims, policies and government support towards an informed and educated nation (institutional level); (2) setting visions, goals and aims for the specific 
library or country specific library and information sector (institutional level); (3) addressing the library workforce's skills, attitudes, motivation, self-efficacy and social capital - that is, the librarians (individual level); (4) selecting one or more lenses to explore the problem and challenge and to find solutions e.g. an information behaviour, information literacy or learning science perspective (institutional and individual level); (5) considering the challenges and trends in society at large - national as well as international (institutional and individual level); (6) working on individual self-efficacy, awareness to the environment (society) and reflection skills to trigger a ripple effect that can contribute to developing informed, educated and empowered nations (individual level); (7) encouraging and supporting autonomous actions of library users in becoming self-efficacious members of an educated nation (individual level); delving into society for additional support such as from grant and funding foundations/ bodies (institutional and individual level).

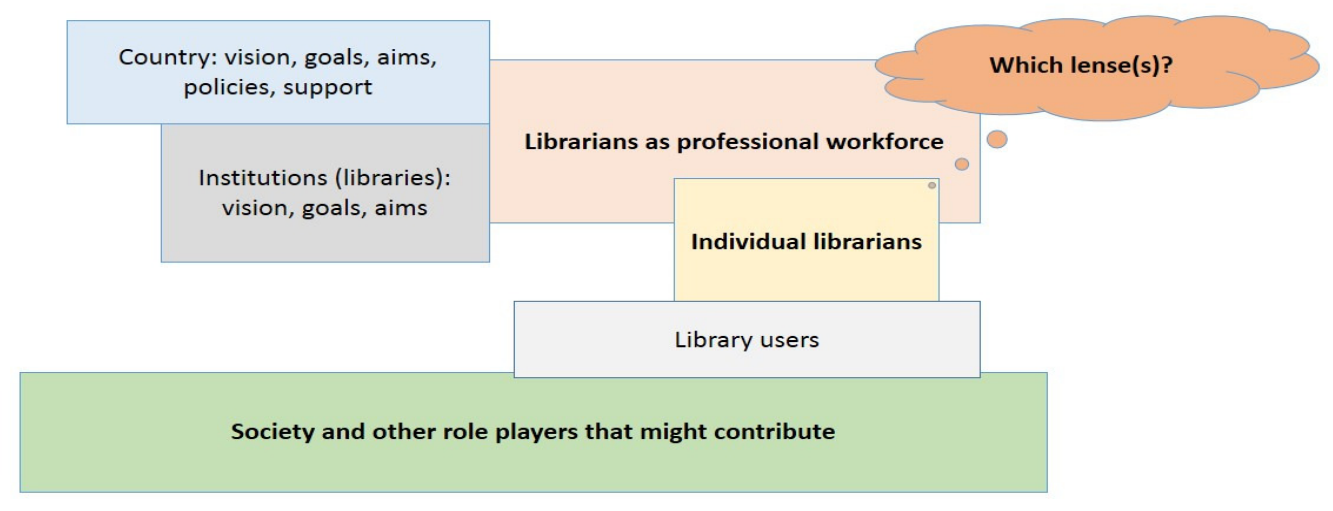
Figure 1: A nascent model for libraries contributing to an informed and educated
nation

\section{DIFFERENT LENSES TO CONSIDER THE CHALLENGE}

How we look, and where we look for problems and solutions determine what we see. From the perspective of art (but also of value here with regard to a complex challenge), Berger (1990, p.1) posits: "Yet this seeing which comes before words, and can never be quite covered by them... what we see is brought within our reach... Our vision is continually active, continually moving, continually holding things in a circle around itself, constituting what is present to us as we are". Libraries' and librarians' contribution to "educated and empowered nations" can be addressed from different points of view - using different lenses. Noting, admitting and pursuing these lenses is the first challenge for libraries as institutions as well as librarians as individuals. From a pragmatic point of view the focus can be on physical solutions such as information and communication technologies (ICTs) and infrastructures (Okonedo, Amusa and Bakare, 2014). From a people's perspective the focus can be on the policy makers, managers, users and non-users of libraries and especially public libraries human beings. Different lenses will reveal different issues to address and research agendas as well as agendas for action that need to be set. The following two paragraphs touch on some of these.

The challenge of informed, educated and empowered nations can be addressed as a social outreach initiative, focusing on an agenda for ensuring social inclusion and eliminating social exclusion with the current focus specifically on digital inclusion (Mervyn, Simon and Allen, 
2014; Thompson, Jaeger, Taylor, Subramaniam and Bertot, 2014), or it can be addressed from an educational lens from the learning sciences (Hollins, 2011; Nieto, 2010) or a collaborative learning/work/information seeking lens (Taber, Howard and Watson, 2010). Social inclusion as well as the other issues noted here can be strengthened by a perspective lens and reflection which is widely written about and noted as a vital aspect of continuing professional development (Rix and Paige-Smith, 2011). According to Rix and Paige-Smith (2011) practitioners such as librarians, on an individual level, need to reflect upon their understanding of the developing context of which we form, and out of which we can form, an informed and educated nation. Perspective and reflection can provide librarians with a tool to reflect upon their own assertiveness towards the collective nature of human development, education and learning. Thus encouraging the consideration of a nation's underlying beliefs, values, knowledge, practices, and assumptions (social inclusion) as they arise within the collective social, cultural, educational and situational development of a nation (Rix and Paige-Smith, 2011).

Taking an information behaviour lens can reveal the importance of considering contexts and the barriers that inhibits information seeking, use and sharing and the possibilities for collaborative information seeking - all in order to deepen understanding of the challenge and the concepts under consideration (Case, 2012; Hansen, Shah and Klas, 2015). A learning sciences lens can support foci on collaboration and how people can work together towards being informed, educated and empowered (Sawyer, 2006). There is also information literacy lenses that can stress the importance of pursuing critical information literacy (Dold, 2014; Smith, 2013; Tewell, 2015) and in combination with information behaviour, guided inquiry lenses, that can raise the level of informedness, exploration, education and empowerment from school level onwards (Hepworth and Walton, 2009; Kuhlthau, Maniotes and Caspari, 2015).

\section{WORDS ASSOCIATED WITH AN “INFORMED AND EDUCATED NATION” AND EMPOWERMENT... AND THE REALITIES TO FACE}

The words that are often associated with informed and educated nations, and empowerment can also shed light on the issues to consider when working towards this, and taking a holistic view. Such words include: open, democratic, accountable, prosperous, productive, innovative, educated, informed, moral, tolerant, united, proud, compassionate, just, caring, safe, and secure (Maruatona, 2011; Maswabi et al., 2011; Newnham, 2009). Building an informed and educated nation is not just about increasing productivity and strength. It is also about issues such as addressing lack of prejudice. Empower is associated with authority, giving the means to, emancipation, setting free, sharing information, and autonomy. Such words indicate the ultimate ideal(s) for an informed and educated nation and also for empowerment, but before getting to these, libraries and librarians need to note and acknowledge many challenges.

The realities faced by nations and societies are really overwhelming. Apart from challenges already noted, there are many deeply serious issues such as poverty, poor education and low levels of literacy (Maswabi et al., 2011; Sawaya et al., 2011). Some countries first need to re-dress the social issues and injustices of the past e.g. women's education, and the needs and rights of marginalised and excluded groups. There is increasing emphasis on patient participation in health decision-making (Oshima and Emanuel, 2013; Veroff, Marr and Wennberg, 2013), changes in societies (the USA was e.g. once considered the most educated nation in the world) (Morrell, 2010; Thifa, 2012). These are only a few of the challenges faced by libraries and librarians setting out to contribute to national plans to work towards an informed and educated nation (Hart and Nassimbeni, 2013; Maswabi et al., 2011; Mgina and Lwehabura, 2011). In general they need to operate with insufficient infrastructures such as insufficient physical space and ICTs, as well as insufficient numbers of skilled staff members and especially staff members who are trained to train others such as 
library users and members from the community, insufficient finances, and insufficient government commitment and support. Librarians and users who are well trained can have a ripple effect in training and affecting the education of others. The same applies to community members in general (Maswabi et al., 2011).

\section{ADDRESSING THE CHALLENGES}

The challenges faced in developing informed, educated and empowered nations are overwhelming, raising the question of how do you eat an elephant? Bit by bit - by starting somewhere. This can be done by addressing problems from different points of view; through different lenses and focusing on different issues. The points raised in the following sections are not intended as comprehensive; merely to raise awareness from all (noted in Figure 1) who can make a difference.

\subsection{Points of departure}

The points noted here need to be considered with the lenses noted earlier, the words associated with the concepts of "informed and educated nations" and empowerment, and bearing those in mind who can address these points from an institutional as well as individual level. The same applies to the other sub-sections.

Building an informed and educated nation requires many things to be addressed, such as literacy, information literacy, adult literacy, digital literacies, media literacy, multicultural literacies and critical literacy (Morrell, 2010). It also requires that collaboration skills, education in healthcare and information literacy, as well as education in ethical issues and cyber security are addressed. There is also education in responsible citizenship, addressing emotional intelligence and especially the importance of affect and emotion (Fourie and Julien, 2014). And many more...

Libraries can start to address challenges by requiring better infrastructures, better access to information resources, especially free information resources, and resources available through open access. They can require better broadband and Internet access, and especially expertise in exploring the potential of mobile access (Moahi, 2013). They need to address training in literacy and information literacy skills, the training of staff, lobbying for funding and government support, advocating for and contributing to the development of government portals (Hart and Nassimbeni, 2013; Moahi, 2013).

\subsection{Focusing on a people's perspective}

In the subject literature there are many reports on how libraries can address challenges regarding infrastructures, collection building, training and continuing professional development (Katz, 2015). What is neglected is to consider the people who need to address the challenges and the people affected from a people's point of view (a social and psychological point of view). Effective change regarding an educated and informed nation needs to start with the policy makers, managers, librarians, users and non-users of libraries, and especially teachers. Their information behaviour, and styles in learning and decisionmaking, and their worldviews need to be considered since these influence their seeking and use of information and problem solving. Often library research focuses on "other" people and determining their efforts, attitude and commitment to things considered important e.g. their attitude to information literacy or preferences for electronic information resources. Librarians who want to make a difference in contributing to an informed and educated nation need to start with the "self" as portrayed in work by Bronstein (2014), Fourie (2006) and Rix and Paige-Smith (2011). They need to study their own information behaviour, learning and thinking styles, habits of reflection and worldviews; their own perceptions of self-efficacy. 
Thus starting with the self, bearing in mind the many different lenses noted in section 4 and working towards a ripple effect.

All people involved, but especially the key role players such as policy makers and managers (e.g. heads of libraries), need to consider what they see in a country's vision, goals, and aims. How, if at all, they go about to learn from other countries, and what has been reported about the successes and problems experienced by other countries, their own institutional visions, goals, and aims, and what can be learned from other institutions. Thinking and reflection are important - as have often been reported in the library and information science and also educational literature (Rix and Paige-Smith, 2011; Sheridan, 1990). From an individual point of view, e.g. as an individual librarian, it is even more important for individuals to capture their "sense-making" in print (or digitally) so that they can read and reflect on it again. Individual librarians or managers need to ask: "What am I making of the challenge to develop an informed and educated nation, the efforts of the library and information service sector, and my own efforts to make a difference?" Many studies on information behaviour and information communication acknowledge the work of Brenda Dervin (Case, 2012). Perhaps a sense-making approach towards studying the information behaviour of politicians, educators and librarians should become more prominent.

The people who can make a difference have skills and shortcomings; gaps in their abilities to address the challenges in building an informed, educated and empowered nation. Such skills need to be audited; programs need to be designed to address shortcomings. Collaboration is important and especially the ability to make the most effective use of available skills. There are many techniques that can be used to assess gaps such as SWOT analysis (Strengths, Weaknesses, Opportunities and Threats), PESTLE (Political, Economic, Social, Technological, Legal and Environmental), PRIMO-F (People, Resources, Innovation and Ideas, Marketing, Operations, and Finance), SMART (Specific, Measurable, Attainable, Realistic and Timely) (Morrison, 2013; Tracy, 2015). Techniques need to be explored to get input from everybody, and to negotiate amongst role players on all levels (institutional, individual and even from the larger society) on addressing challenges.

Means need to be developed to maintain existing library users and to recruit new users and explore their potential input, to learn who they are and what their needs are, and how they can get involved in community capacity building. Dorner, Gorman and Calvert (2015) provide innovative ideas on determining user needs.

Furthermore means need to be explored to reach out to non-users. Who are they? How can they be identified, and how can librarians reach out to them and understand their information needs? There are many studies reported on information behaviour and information practices that can serve as point of departure (Case, 2012). What can be learned from theserelevant to libraries who want to contribute to the building of an informed and educated nation? The available literature might be explored for idea generation, and alternative techniques of data collection - both exercises in their own right.

When dealing with education, capacity building and empowerment it is important to acknowledge that we are dealing with human beings, and that we as researchers, librarians, managers or policy makers are human beings. Issues that becomes important and that requires consideration will then be motivation, enthusiasm, and self-efficacy.

\subsection{Some examples of efforts}

Although there are many examples of efforts from libraries, not many of these are reported in the subject literature. Examples that can be noted include the Sesigo Project in Botswana, aligned with Vision 2016 (www.vision2016.co.bw) and the Global Libraries Initiatives Projects supported by the Bill and Melinda Gates Foundation 
(http://www.gatesfoundation.org/). In fact grant and funding foundations/bodies such as the Bill and Melinda Gates Foundation and UNESCO might play an important role in shaping initiatives towards informed, educated and empowered nations and the roles of libraries (institutional) and librarians and users (individual).

\subsection{Value of an information behaviour perspective as lense}

The importance of understanding information behaviour and information practices has often been noted in the literature (Ford, 2015). It can also inform attempts to develop informed, educated and empowered nations. Information behaviour is an encapsulating term for all human behaviour related to information, such as recognising and expressing information needs, information seeking, information searching, information retrieval, information encountering, browsing, information avoidance, information use, and unawareness of information needs (e.g. definition by Tom Wilson) (Case, 2012). Information practice is a related term - often associated with everyday life and "mastery of life" (e.g. the interpretation by Reijo Savolainen) (Savolainen, 2007).

Studies of information behaviour and practice can be of great benefit to libraries. It can reveal the information needs and preferences, and various information related activities. Libraries need to consider user patterns for viewing information, for listening to information and for reading. They need to note generational differences, changes over time, etc. There are many standard methods for collecting data to understand information behaviour such as questionnaires, interviews, focus-group interviews, and observation (Pickard, 2013). But other methods also need to be explored such as motivational interviews, action research and participatory action research, the Delphi method and slowDelphi method (Poirier and Robinson, 2014). Although a lack of sufficient staff, and especially staff with training and research skills have been noted for libraries there should be efforts for ongoing research, and empowerment. Informed and educated librarians should be empowered to work towards nations to become informed, educated and empowered.

Much has already been published about the preferences of library users - on whether they prefer free newspapers, using mobiles, social networking sites, games and gamification (Phetteplace, and Felker, 2014). Ellison et al. (2014) noted how the utilisation of social networking sites can enable greater access to resources, knowledge building, co-learning and social interactions. Librarians can draw on this to promote social learning and selfdirected learning (Ellison, et al., 2014; Okada et al., 2012). Through reflection they can explore solutions to reach users.

\subsection{Value of an information literacy perspective as lense}

An information literacy perspective, specifically work on guided inquiry (i.e. the process of carefully planned and supervised intervention by a teacher to guide students throughout the process of inquiry to construct a higher-level of thinking and personal understanding) can be applied in various contexts (Hepworth and Walton, 2009; Kuhlthau, Maniotes, and Caspari, 2015). In information literacy training there need to be recognition of feelings, emotions, and uncertainties. These can link to many of the words that are typically associated with an informed and educated nation and empowerment (Section 3) - tolerant, safe and secure. The work of Vygotsky (1978) (zones of proximal development) and Carol Kuhlthau (2004) (zones of intervention), and allowing people to have "fun" when learning new skills can come into play. So can noting the importance of flow (Csikszentmihalyi, 1996).

\subsection{Value of a learning science perspective as lense}

Libraries need to be safe spaces for people to learn and work with information. Insight from the learning sciences can be useful. "Learning sciences is an interdisciplinary field that 
studies teaching and learning. The sciences of learning include cognitive science, educational psychology, computer science, anthropology, sociology, neuroscience, and other fields" (Sawyer, 2006). Librarians need to further their educational roles. They need to consider Pedagogic and Andragogic approaches in reaching out to children as well as older people amongst minority groups, the poor, women, and people with disabilities and special needs.

In creating safe and pleasant learning spaces librarians need to take a holistic view recognising the complexities and the opportunities. They can re-think alliances between different library types such as public and academic libraries (thus moving from the individual to the institutional level) and with scholars who might have better infrastructures and access to information resources. It might be good to map role players and stakeholders from the national as well as international community that can contribute to specific actions such as grant and funding foundations/bodies.

\section{A FOCUS ON EMPOWERMENT AS ULTIMATE AIM FOR INFORMED AND EDUCATED NATIONS}

As noted in the title and introduction to the paper, more than informing and education is required for success and sustainability. The focus should also be on empowerment... to give somebody control over their own life and the situations they are in. Participation in the development of libraries as spaces and information services, training initiatives and addressing self-efficacy is especially important, for example through participatory research and specifically participatory action research. Improving self-efficacy and social connections (i.e. social capital) then becomes more important.

Self-efficacy refers to an individual's belief in his or her own capacity to execute behaviours necessary to produce specific performance attainments (Bandura, 1977). It reflects confidence in the ability to exert control over one's own motivation, behaviour, and social environment. Self-efficacy has been noted with regard to information behaviour and learning, as well as the use of information technology. Librarians need to start by noting the importance of their own self-efficacy e.g. as in the study by Bronstein (2014) with library and information science professionals. Social capital concerning the expected collective benefits derived from networking and cooperation, means to exchange and share information, and online communities and connections for all age groups and issues become important.

According to Pootinga (2012, p. 287), social capital, "as reflected in social trust, reciprocity, and civic participation", is connected to advanced levels of a community's health. As a result, Poortinga (2012, p. 287) puts forward the five capital model. Librarians can utilise this to promote the sustainable development of a resilient and empowered community, through providing a composed combination of economic capital (e.g. income), built capital (e.g. access to services), natural capital (e.g. access to green space), human capital (e.g. skills and education), and social capital (e.g. social networks and relationships) resources.

\section{ADDING DETAIL FOR FUTHER RESEARCH TO THE NASCENT MODEL}

As for the nascent model suggested in Figure 1, the following can be considered as points of departure in taking research to the next level:

- Determining and working from the country's vision, goals, aims, policies and government support towards an informed and educated nation (institutional level) - if this is not in place then librarians can form advocacy groups to lobby for policies and commitments, and present reviews of what has been done in other countries.

- Setting visions, goals and aims for the specific library or country specific library and information sector (institutional level) - this would require an understanding of the 
status quo in the country, collaborating with people in other sectors such as education and health, surveys, and again reviews of what is done in other countries and library sectors.

- Addressing the library workforce's skills, attitudes, motivation, self-efficacy and social capital - that is, the librarians on individual level. This would require surveys and skill audits.

- Selecting one or more lenses to explore the problem and challenge and to find solutions e.g. an information behaviour, information literacy or learning science perspective (institutional and individual level). This paper highlighted some key issues for these lenses, but there is much more to consider.

- Considering the challenges and trends in society at large - national as well as international (institutional and individual level) - environmental scanning and current awareness services might be useful in this regard.

- Working on individual self-efficacy, awareness to the environment (society) and reflection skills to trigger a ripple effect that can contribute to developing informed, educated and empowered nations (individual level) - this will require librarians to commit to self-development - but for a specific purpose, namely contributing to a bigger course.

- Encouraging and supporting autonomous actions of library users in becoming selfefficacious members of an educated nation (individual level); delving into society for additional support such as from grant and funding foundations/ bodies (institutional and individual level).

\section{CONCLUSION}

Contributing to an informed and educated nation is possible and manageable - even with limited resources. There are boundless opportunities, with the secret ingredients being information, collaboration, reflection, and including and reaching out to all citizens, and not to expect immediate perfect results. This paper merely scratch the surface of what need and can be done with the intention to encourage librarians to embark on this road.

\section{References}

Addo, M.O. (2014), A reading nation is an informed nation - Matilda Amissah-Arthur, available at: http://www.ghanaweb.com/GhanaHomePage/NewsArchive/A-reading-nation-isan-informed-nation-Matilda-Amissah-Arthur-328360 (accessed 10 January 2016).

Ash-Argyle, R. and Shoham, S. (2014), "Professional self-efficacy and role perception of school librarians and their impact on the development of students' information literacy: an evidence-based study", Journal of Information Literacy, Vol. 8 No. 2, pp. 118-140.

Bandura, A. (1977), "Self-efficacy: toward a unifying theory of behavioural change", Psychological Review, Vol. 84 No. 2, pp. 191-215.

Berger, J. (1990), Ways of seeing, Penguin Classics, London, UK.

Britz, J.J. (2008), "Making the global information society good: a social justice perspective on the ethical dimensions of the global information society", Journal of the American Society for Information Science and Technology, Vol. 59 No. 7, pp. 1171-1183.

Bronstein, J. (2014), "The role of perceived self-efficacy in the information seeking behavior of library and information science students", Journal of Academic Librarianship, Vol. 40 No. 2, pp. 101-106. 
Case, D.O. (2012), Looking for information: A survey of research on information seeking, needs and behaviour, Emerald Group Publishing, Bingley, UK.

Csikszentmihalyi, M. (1996), Creativity: flow and the psychology of discovery and invention. Harper, New York.

Dold, C.J. (2014), "Critical information literacy: a model for transdisciplinary research in behavioral sciences", Journal of Academic Librarianship, Vol. 40 No. 2, pp. 179-184.

Dorner, D.G., Gorman, G.E. and Calvert, P.J. (2015), Information needs analysis principles and practice in information organizations, Facet Publishing, London, UK.

Eden, B.L. and Eden, B.L. 2015, "Metaliteracy: reinventing information literacy to empower learners", Journal of Electronic Resources Librarianship, Vol. 27, No. 1, pp. 62-63.

Ellison, N.B., Vitak, J., Gray, R. and Lampe, C. (2014), "Cultivating social resources on social network sites: Facebook relationship maintenance behaviors and their role in social capital processes", Journal of Computer-Mediated Communication, Vol. 19 No. 2014, pp. 855-870.

Fonda, J. (2009), Adolescent pregnancy must become a priority for all Americans, available at: http://rhrealitycheck.org/article/2009/05/06/adolescent-pregnancy-must-become-apriority-all-americans/ (accessed 10 January 2016).

Ford, N. (2015), Introduction to information behaviour, Facet Publishing, London, UK.

Fourie, I. (1999), "Empowering users - current awareness on the Internet", The Electronic Library, Vol. 17 No. 6, pp. 379-388.

Fourie, I. (2006), How LIS professionals can use alerting services, Chandos Publishers, Oxford, UK.

Fourie, I. (2015), "Developing an informed and educated nation". Unpublished conference paper delivered in at the Library Management Conference, 30 September (Johannesburg, South Africa).

Fourie, I. and Julien, H. (2014), "IRS, information services and LIS research - a reminder about affect and the affective paradigm... and a question", Library Hi Tech, Vol. 32 No. 1, pp. 190-201.

Hansen, P., Shah, C. and Klas, C.P. (eds). (2015), Collaborative information seeking: best practices, new domains and new thoughts, Springer, Heidelberg, NY.

Hart, G. and Nassimbeni, M. (2013), "From borders and landscape to ecosystem: reconfiguring library services to meet the needs of South African youth", South African Journal of Libraries and Information Science, Vol. 79 No. 1, pp. 13-21.

Hepworth, M. and Walton, G. (2009), Teaching information literacy for inquiry-based learning, Chandos Publishers, Oxford, UK.

Hollins, E.R. (2011), "The meaning of culture in learning to teach". Journal of Teacher Education, Vol. 62 No. 4, pp. 395-407.

Guadagnoli, E. and Ward, P. (1998), "Patient participation in decision-making", Social Science and Medicine, Vol. 47 No. 3, pp. 329-339. 
Igiamoh, V.E. and Ogunwemimo, O.A. (2013), "Re-positioning public libraries in Nigeria for social inclusion services", World Libraries, Vol. 20 No. 2, available at: http://0ojsserv.dom.edu.innopac.up.ac.za/ojs/index.php/worldlib/article/viewArticle/486/469 (accessed 11 January 2016).

Jaeger, P, Shilton, K. and Koepfler, J. (2016), "The rise of social justice as a guiding principle in library and information science research", Library Quarterly, Vol. 86 No. 1, pp. 19.

Katz, A. (2015), Libraries, literacy and technology: A new training module for public librarians in developing countries targeted at integrating libraries into literacy programs. In World Library and Information Congress: IFLA General Conference and Assembly, August 2015, Cape Town, SA, available at: http://library.ifla.org/1205/1/118-katz-en.pdf (accessed 11 January 2016).

Khan, S. and Bhatti, R. (2012), "A review of problems and challenges of library professionals in developing countries including Pakistan", Library Philosophy and Practice, available at: http://0-digitalcommons.unl.edu.innopac.up.ac.za/libphilprac/757/ (accessed 11 January 2016).

Kuhlthau, C.C. (2004), Seeking meaning: A process approach to library and information services. $2^{\text {nd }}$ ed. Libraries Unlimited, Westport, CT.

Kuhlthau, C.C., Maniotes, L. and Caspari, A.K. (2015), Guided inquiry: learning in the 21st century, $2^{\text {nd }}$ ed., Libraries Unlimited, Santa Barbara, CA.

Mali, M. G. (1989), Education of Masses in India. Mittal Publications, New Delhi. India.

Maruatona, T. (2011), "Lifelong learning and the pursuit of a vision for sustainable development in Botswana", Studies in Continuing Education, Vol. 33 No. 2, pp. 121-138.

Maswabi, T., Sethate, T., Sebusang, S. and Taolo, R. (2011), "Public libraries: pathways to making Botswana an educated, informed nation", Library Review, Vol. 60 No. 5, pp. 409420.

Mervyn, K., Simon, A. and Allen, D.K. (2014), "Digital inclusion and social inclusion: a tale of two cities", Information, Communication and Society, Vol. 17 No. 9, pp. 1086-1104.

Mgina, S. and Lwehabura, M. (2011), "Status of secondary school libraries under the secondary education development plan: Case study of Dodoma Municipality, Tanzania", African Journal of Library, Archives and Information Science, Vol. 21 No. 2, pp. 159-168.

Moahi, K.H. (2013), "Leveraging public libraries and information and communication technologies (ICTs) to deliver information services for development in Botswana: towards the information society", available at:

http://168.167.8.4/xmlui/bitstream/handle/10311/1145/Moahi_Unpublished_2010.pdf?seque nce $=1$ (accessed on 11 January 2016).

Morrell, E. (2010), "Critical literacy, educational investment, and the blueprint for reform: An analysis of the reauthorization of the Elementary and Secondary Education Act", Journal of Adolescent and Adult Literacy, Vol. 54 No. 2, pp. 146-149.

Morrison, M. (2013), Strategic business diagnostic tools - theory and practice, CreateSpace Independent Publishing Platform, London, UK. 
Nakhoda, M. and Rahimian, S. (2015), "Factors affecting empowerment of female librarians, views of female managers of Tehran public libraries", Library Management, Vol. 36, No. 8, pp. 663-672.

Nieto, S. (2010), Language, culture, and teaching: critical perspectives, Routledge, New York, USA.

Nkwocha, O.G. (2011), Effective leadership in Nigeria: practical ways to build effective, inspiring, transformational and visionary leadership and governance in Nigeria, AuthorHouse, Bloomington, USA.

Newnham, D.S. (2009), "Implementing inclusive education in schools", Commonwealth Education Partnerships, available at: http://www.cedol.org/wp-content/uploads/2012/02/6365-2009.pdf (accessed on 10 December 2015).

Okada, A., Mikroyannidis, A., Meister, I. and Little, S. (2012), "'Colearning' - collaborative networks for creating, sharing and reusing OER through social media", Cambridge 2012: Innovation and Impact - Openly Collaborating to Enhance Education, 16-18 April 2012, Cambridge, UK, available at: http://oro.open.ac.uk/33750/2/59B2E252.pdf (accessed on 14 December 2015).

Okonedo, S., Amusa, O.I. and Bakare, O.D. (2014), "ICT Influence on globalization of library and information services delivery in academic libraries in South West, Nigeria", Information and Knowledge Management, Vol. 4 No. 12, pp. 205-212.

Oshima L.E. and Emanuel, E.J. (2013), "Shared decision making to improve care and reduce costs", New England Journal of Medicine, Vol. 368 No. 1, 6-8.

Phetteplace, E. and Felker, K. (2014), "Gamification in libraries", Reference and User Services Quarterly, vol. 54, no. 2, pp. 19-23.

Pickard, A.J. (2013), Research methods in information, $2^{\text {nd }}$ edition. Facet Publishing, London (UK).

Poirier, E. and Robinson, L. (2014), "Slow Delphi: An investigation into information behaviour and the slow movement", Journal of Information Science, Vol. 40, No. 1, pp. 88-96.

Poortinga, W. (2012), "Community resilience and health: the role of bonding, bridging, and linking aspects of social capital”, Health and Place, Vol. 18 No. 2012, pp. 286-295.

Real, B., Bertot, J. and Jaeger, P. (2014), "Rural public libraries and digital inclusion: issues and challenges", Information Technology and Libraries, Vol. 33 No. 1, pp. 6-24.

Rix, J. and Paige-Smith, A. (2011), "Exploring barriers to reflection and learning - developing a perspective lens", Journal of Research in Special Educational Needs, Vol. 11 No. 1, 30-41.

Savolainen, R. (2007), "Information behaviour and information practice: reviewing the umbrella concepts of information-seeking studies", Library Quarterly, Vol. 77 No. 2, pp. 109-132.

Sawaya, J., Maswabi, T., Taolo, R., Andrade, P., Moreno Grez, M., Pacheco, P. and Jezowska, J. (2011), "Advocacy and evidence for sustainable public computer access: experiences from the Global Libraries Initiative", Library Review, Vol. 60 No. 6, pp. 448-472. 
Sawyer, R.K. (ed.) (2006), Cambridge handbook of the Learning Sciences. Cambridge University Press, Cambridge, UK, pp. 409-426.

Sheridan, J. (1990), "The reflective librarian: some observations on bibliographic instruction in the academic library", Journal of Academic Librarianship, Vol. 16 No. 1, pp. 22-26.

Smith, L. (2013), "Critical information literacy instruction for the development of political agency", Journal of Information Literacy, Vol. 7 No. 2, pp. 15-32.

Stilwell, C. (2016), "The public library as institutional capital: towards measures for addressing social inclusion and combating poverty", Information Development, Vol. 32 No. 1, pp. 44-59.

Taber, N., Howard, L. and Watson, G.C. (2010), "Researcher subjectivities as a conceptual frame in collaborative research: how exploring the experiences of adult educators led to examining researcher lenses", Canadian Journal for the Study of Adult Education, Vol. 23 No. 1, pp. 39-54.

Tewell, E. (2015), "A decade of critical information literacy", Communications in Information Literacy, Vol. 9 No.1, pp. 24-43.

Thifa, D. (2012), "20 Best education systems in the world", MBC Times, available at: http://www.mbctimes.com/english/20-best-education-systems-world (accessed 11 January 2016).

Thompson, K.M., Jaeger, P.T., Taylor, N.G., Subramaniam, M. and Bertot, J.C. (2014), Digital literacy and digital inclusion: Information policy and the public library. Rowman and Littlefield, London, UK.

Tracy, B. (2015), "Creativity and problem solving". American Management Association, available at: http://www.amanet.org/training/articles/Creativity-and-Problem-Solving.aspx (accessed 11 January 2016).

UNESCO. (2015), "Call for registration for UNESCO's online media and information literacy course for youth", Communication and information sector, available at:

http://www.unesco.org/new/en/communication-and-information/resources/news-and-infocus-articles/allnews/news/register_now_unescos_online_media_and_information_literacy_course_for_yout h-1/\#.VpNRg_197IU (accessed 11 January 2016).

UNESCO. (2000), Tanzania Development Vision 2025, available at: http://www.unesco.org/education/edurights/media/docs/061eb2eed52b8f11b09b25a8845436 f19d5ae0ad.pdf (accessed 10 January 2016).

Veroff, D., Marr, A. and Wennberg, D.E. (2013), "Enhanced support for shared decision making reduced costs of care for patients with preference-sensitive conditions", Health Affairs, Vol. 32 No. 2, pp. 285-293.

Vygotsky, L.S. (1978). "Interaction between learning and development" (M. LopezMorillas, Trans.). In M. Cole, V. John-Steiner, S. Scribner, and E. Souberman (Eds.). Mind in society: The development of higher psychological processes. Harvard University Press Cambridge, MA. 